\title{
Baptism and its Consequences for our Life
}

\author{
doc. ThDr. Michal Hospodár, PhD. \\ University of Prešov in Prešov, Greek Catholic Theological Faculty
}

\begin{abstract}
Biological life naturally arises out of marital love when man and woman in their own self-giving become mediators of the child's conception. It is scientifically proven that during mother 's pregnancy as well after the birth, the child's mental development is nourished by mutual love of the parents and their love for the child himself. Supernatural life arises in the soul through God's gift of love and it is nourished by this love. In order for God's life to arise within us and to give us assurance of faith, Jesus Christ established seven mysteries (sacraments) that affect important stages of the whole human life. In this article we focus on the rediscovery of the fundamental theological contents and pastoral sense of this mystery, and thus we reflect actual situation and experience of the Slovak Church.
\end{abstract}

\section{Notion Concept of Baptism}

The word "krst" (the Slovak expression of the word Baptism) has its origin in the ancient German word krist - Christ, in Greek Christos - the anointed. The Slovak word "krstit" has its origin in the old German word "kristen", which means to make followers of Christ. In Greek it is the word baptizein, according to the main rite (ceremony), which means to immerse. In the liturgical scripts of the Byzantine rite it is a word prosviščeniem, which means to enlighten, since a catechumen has received the true light - Jesus Christ into his life and has become the son of light. (Cf. 1 Sol 5,5)

In addition to the basic understanding of the notion idea of Christ's Baptism as a sacrament, we encounter in theological literature the expression "Baptism in the Holy Spirit". The excellent catholic exegete of the New Testament Francis A. Sullivan explains that the term "Baptism in the Holy Spirit" corresponds to two understandings and meanings. In the theological sense, each member of the Church was baptized in the Spirit because he received the Christian initiation. In the charismatic sense, "Baptism in the Holy Spirit" is understood as a process of growth, when 
the Holy Spirit, given in the celebration of initiation, reaches the conscious experience. ${ }^{1}$

The Church's tradition discerns two other terms relating to Baptism: Baptism of blood and one of desire. Baptism of blood for those who suffer death for the sake of the faith without having received Baptism are baptized by their death for Christ and in Christ (CCC 1258). Baptism of desire lies in the act of perfect love that loves God above all. The Catechism of the Catholic Church literary teaches: "For catechumens who die before their Baptism, their explicit desire to receive it, together with repentance for their sins, and charity, assures them the salvation that they were not able to receive through the sacrament." (CCC 1259) According to st. Thomas Aquinas, Baptism of desire does not operate ex opere operato (through the act itself), but ex opere operantis through the personal act of love and strength, to which God responds with his own love. ${ }^{2}$ Grace can be achieved as a result of the Sacramental Baptism, but both, Baptism of blood and one of desire are not the sacraments.

\section{Types of Baptism in the time of Jesus}

In the Old Testament, Baptism appears as a goal of long-lasting preparation and as a result of Christ's will in the New Testament. In the time of Jesus, there were various types of Baptism: the Baptism of Qumrans (Essenes), the Baptism of Proselytes and the Baptism of John the Baptist. In their core, they followed the command of circumcision, which indeed was the outer sign of belonging to the chosen people, the sign of a covenant with Yahweh and the guarantee to participate in his promises.

The next necessary thing to join God's people was the individual or collective rite to engage with the covenant made by the fathers. At the Baptism of Qumrans - one of the Jewish sects - two years long examination of candidates and learning about one true God and his marvelous wonders in the human history came first. After they had chosen a path for life then the rite of the Baptismal initiation was accomplished.

Proselytes formed the other religious group. They were pagans who had permanently lived in the Jewish environment and from the religious view they had been incorporated into the Jewish society. They had knowledge of the only God, about idols, positive and negative commands, and good and evil. They were circumcised and baptized, too. They had access

\footnotetext{
${ }^{1}$ Cf.. SUlLIVAN, F. A.: Charisms and Charismatic renewal, Bratislava: Serafín, 1982, s. 68. AQUINAS, T.: Summa theologica III. 66, 11.

${ }^{2}$ Cf. DUFOUR, X. L: Dictionary of Biblical Theology, Zagreb: Kršćanskaja sadašnjost, 1990, s. 483.
} 
to the Passover feast and sacrifice. ${ }^{3}$ These types of baptisms, even though they show similarities with the sacramental Baptism, do not reflect any salvific event, nor they have a minister; the candidate for baptism immerse in water himself. The apparent significant change can be seen in John the Baptist. He preached repentance to Abraham's offspring that had been awaiting the Messiah. He offered baptism not only to sinners and proselytes, but to all Jewish people. His baptism consisted in confession of sins and an effort to convert. However, his baptism could not be considered as sacramental, yet it was considered to be a preparatory baptism of water, which had prepared for the messianic baptism of the Holy Spirit. ${ }^{4}$ John knew, he was baptizing only with water (Cf. Jn 1:26), but Christ, coming after him would baptize with the Holy Spirit and fire. (Cf. Mt 3:11; Lk 3:16)

\section{Baptism of Jesus}

Jesus even though he was without sin wanted to be baptized by John's baptism. (Acc Mt 3:13). He viewed it as a step willed by God himself, the last preparation for the messianic times, and thus he wanted to fulfill the redemptive justice of God who had been managing the plan of salvation. ${ }^{5}$ In the act of being baptized by John, Jesus undertook the rite, which had existed before, and gave it new power and fulfillment. The voice of the Father was heard at Jesus' baptism in the Jordan: "This is my beloved son..." (Mt 3:17). In this voice a new adoptive sonship of all the baptized believers is announced, along with it incorporates all the baptized into Christ. Simultaneously, the Holy Spirit descended upon Jesus in the form of a dove, and thus the whole revelation of the Trinity was crowned in it. Jesus' Baptism in the Jordan pointed out the mystery of his suffering, which came to its perfection in the paschal mystery. "The blood and water that flowed from the pierced side of the crucified Jesus are types of Baptism and the Eucharist, the sacraments of new life. From then on, it is possible "to be born of water and the Spirit" in order to enter the Kingdom of God." (CCC 1225) The newness of the sacramental Baptism established by Christ lies in this: It is a sign of the very act of God and Holy thing. Christ's suffering, which was an archetypal Baptism of the Bride - the Church - is indeed the very Act of God and the Holy thing.

The Church teaches that Baptismus aque a Christo institutus, est proprie dictum sacramentum. It means that Baptism with water, established by

\footnotetext{
${ }^{3}$ Cf. DELORME, J.: La pratique du babteme dans le Judaisme contemporain des origines chrétiennes. Lumiere et Vie, 1956, s. 165n.

${ }^{4}$ ĎURICA, J. (ed.): New Testament with comments and marginals of The Jerusalem Bible, Trnava: Dobrá kniha, 2008, s. 15.
} 
Christ, is indeed the real sacrament. (De fide ex Trident n. 600) It contains all the essential conditions needed for the sacrament: an external character - washing off with water and invocation of the Holy Trinity, an output of grace to ensure new birth and salvation. It even has a lasting impact contained in Jesus' words, after sending the disciples into the world: "And look, I am with you always; yes, to the end of time." (Mt 28:20)

\section{Effects of Baptism}

According to the catholic teaching there are two effects of Baptism: an indelible mark (character) and grace. A man is united with Christ who is the head of the body through that character; he becomes a member of the Church, in her authority he is led towards eternal happiness and is able to receive other sacraments and church's blessings. ${ }^{5}$

Each man, whose Baptism is valid, has received the sacramental character within his soul. This character is unperishable and unrepeatable.

The Council of Trident defined the effects of Baptismal grace as follows: Gratia sacramentalis Baptismi est gratia regenerativa, qua plene remittuntur omnia peccata poenaeque peccatis debitae. ${ }^{6}$ (De fide ex Trident sess. V, can. 5) This new birth comes forth from the outpouring of bestowed habitual grace. God's grace can be received only if man disposes himself to accept the faith, and no grave sin is an obstacle to its reception. The more the receiver disposes himself, the more grace is bestowed in the sacrament.

The necessity of Baptism, as well its effects are revealed in Christ's discussion with Nicodemus: "Very truly I tell you, no one can enter the kingdom of God unless they are born of water and the Spirit." (Jn 3:5) In the sense of Jesus' words, Baptism is new birth in the Holy Spirit. It is the very first mysterious touch of the soul with God through the sacramental grace having been preceded by the forgiveness of original sin, as well as all personal sins, and the punishments of all sins. Nicodemus, an expert in the Jewish religious law didn't quite understand Jesus words because they had a prophetic character, which was later unveiled. New birth as a relevant effect of Baptism was later theologically developed by the apostle Paul in his letters. The Catechism of the Catholic Church sums up various aspects of the new birth as follows:

- To receive adoptive sonship (Cf. Gal 4:5)

- To share God's nature (Cf. 2 Pt 1:4)

\footnotetext{
5 TANQUEREY, AD.: Brevior synopsis theologiae dogmaticae, editio decima, DESCLÉE\&SOCII, 1956, s. 588.

${ }^{6}$ TANQUEREY, AD.: Brevior..., s. 592. (Translation: Sacramental grace of Baptism is the grace of new birth, if it fully forgives all sins and their punishments).
} 
- To be incorporated into Christ's body ( Cf. 1 Cor 6:15)

- To share Christ's inheritance (Cf. Rom 8:17) $6: 19)^{7}$

- To sanctify our bodies to be the temples of the Holy Spirit (Cf. 1 Cor

Besides the invisible aspects of Baptism, Baptism is at the same time the incorporation of the baptized into the visible community of all those who have already been baptized - into the Church. Baptism is performed in the Church and at the same time, the Church is being constituted by it. The second Vatican council teaches that the man, who has knowledge of the necessity of Baptism for his salvation and thus rejects it, cannot be saved without entering the Church. (Cf. AG, 7) On the other hand, Lumen Gentium states (ch. 7): "Those also can attain to salvation who through no fault of their own do not know the Gospel of Christ or His Church, yet sincerely seek God." Due to Baptism, the believer is not only an individual, he becomes a member of God's people. He becomes part of the Church that in Peter's words means "a chosen race, a kingdom of priests, a holy nation, a people for His own possession". (1 Pt 2:9). Even if someone formally left the Church, by the power of Baptism, he would permanently remain in it.

\section{The mystery of new birth}

The very foundation of Baptism comes from Christ and the rite has been established by the Church. The distinctiveness of this sacrament lies in the following: the very first supernatural gift of grace is given to every man merely in the sacrament of Baptism. As stated in the Code of Canons for Byzantine Churches, the truly received Baptism - baptismus in re enables man to receive other sacraments (CCEO can 675 \$2). ${ }^{8}$

Baptism seems to be the gateway towards the other sacraments. The sacramental Baptism causes an existential change in the life of the baptized person. The Holy Spirit is the main cause of that change, water is an instrumental cause. This inexplicable outpouring of God's life into our soul performed by the Holy Spirit is a mystery even to theologians. At the moment when the sacrament of Baptism is being performed, God temporary gives a special power to the water to be the actual instrument of sanctification of the person. As the Holy Spirit is the real and physical cause of sanctification of the soul, so water (sacrament) is the real physical instrument through which man is being sanctified.? Some church fathers

\footnotetext{
${ }^{7}$ Cf. CCC, 1265.

${ }^{8}$ To be distinguished: baptismus in re, means real baptism and baptismus in voto, which is an intention or desire to be baptized.

${ }^{9}$ DACÍK, R.: God in the Sacraments, Olomouc: Krystal. 1948, s. 15.
} 
explain this through images that partially help us to penetrate the character of this truth. The ray of sunlight passes through mud, yet it looses nothing of its purity. Otherwise, the same water flows through an iron pipe, as well as, trough the golden one. Those who were born again in Baptism can from the hand of the church's ministers receive the other sacraments, and thus find its fulfillment in eternity. Still, it is necessary to know that the very first touch of God's love for man takes place in the sacrament of Baptism.

\section{Baptism of unborn infants}

Many times parents struggle with the question: what happens to my child who for some reason wasn't baptized and died? The most known solution, a theory of limbo (lat. Limbus - edge), a place where unborn children do not suffer, but are deprived of beatific vision of God, proved to be insufficient. It was just a theological view, which wanted to reduce tensions between God's justice that could not condemn the person for something he had not been responsible for, and the necessity of Baptism, without which salvation is impossible. Even though the Limbo theory spread out, it has never been the essential teaching of the Church. The international theological commission of the Vatican issued a document entitled 'The hope of salvation for infants who die without being baptized'. New chance of salvation for those, who without any own endeavor, received no sacramental Baptism, has been opened. "God has bound salvation to the sacrament of Baptism, but He himself is not bound by His sacraments."(CCC, 1257) The most given reasons for this hope are the general will of God to save all those, as well his merciful love. In the document the commission admits that the Church cannot comprehend the whole truth about these infants because this truth has been not explicitly revealed.

\section{Pastoral care of Baptism}

Baptism is the very first and fundamental sacrament in the spiritual organism of every believer. From the pastoral point of view Baptism is conferred in faith and for the sake of the faith. Christ emphasized both realities in one organic demand for salvation by his words: "Whoever believes and is baptized will be saved;" (Mk 16:16). Nowadays, Baptism seems to be the forgotten sacrament in the Church (card. Ratzinger). Not in the sense to be ignored by believers, but the dimension of its understan- 
ding and its necessity for our lives have been lost. ${ }^{10}$ It is right to assume, that unless preparation for the sacrament of Baptism is done on a higher level of pastoral care, it will begin a schizophrenia of faith (sacrament) and of life itself, and we will harvest its fruit in the future. The decline of faith results in so-called parish registered Christians.

Baptism is a concept well known and established in the language of society. However, its true meaning is intentionally disguised by neo-pagan custom, spread through mass media, as watered down wine on various items. Czech theologian f. Ambros calls for new reconsideration who the baptized person is, in constitutes his radical newness, what is the way of his perception, reflection and thinking... ${ }^{11}$ From this follows that our inherited Christianity must be transformed into a Christianity that is consciously chosen, and known as before. Here we encounter several difficulties:

- Preparation for baptism nowadays in Slovakia consists of 1-2 meetings with a priest, but this is not an effective catechization of the whole family.

- An effort should be made to instruct God-parents before Baptism (explain different elements, their role, realization of adult baptism at BO, pastoral conditions, symbols of the baptismal rite, time of baptism on Sundays in the presence of other believers). ${ }^{12}$

- There is a Narrow understanding of Baptism in the end being the duty of the parents., This way Baptism is the beginning of the organic building of personal faith.

- Due to the lack of sufficient and permanent formation of the baptized, there is a link missing between baptism and life. When there are parents present at the baptismal preparation do not let go of them. (for inst. Let them come for a meeting once a month), and similarly, it is necessary to take advantage of the pastoral opportunities (married couples after their wedding ceremony, children after the first communion, young people, etc). Those groups should be biblically educated despite the pastoral over extra work it brings.

- We need to re-discover the power of the Church's fellowship. People are spiritually dying if they do not live in Christian fellowship. A child

\footnotetext{
${ }^{10}$ In 2011, 42235 Baptisms were conferred in the Catholic Church in Slovakia. 37715 children under the age of 1, 2695 Baptisms from the age of 1-7, 807 above the age of 18 . Datas are taken from the statisticcs of KBS (Slovak Bishop's conference).

${ }^{11}$ Porov. ŠPIDLÍK, T. - RUPNIK, M. I.: New ways of pastoral theology, Olomouc: Refugium Velehrad-Roma s.r.o., 2008, s. 69.

${ }^{12}$ The Board of Family at KBS in Slovakia issued the booklet with the title, Meetings of the paretns before the Baptism of their child. Vyd. Michala Vaška, 2004. The booklet gives brief Christian views on the gift of new life, instruction for prayer life in the family, and explanation of the sacrament of Baptism and its rite.
} 
being baptized without community cannot find the fullness of its Christian identity. The family is therefore called "the domestic church" in order for children not to be spiritually aborted.

- Baptism has become a certain form of magic to people. However, Baptism is a mystery, that's why there are so many contradictory opinions and views regarding this sacrament.

- approved Church's movements like Neocatechumenate, play an important role in the discovery of the value of Baptism, . It basically replicates the early Christian catechumenate applied to the already baptized. But they merely gather an exclusive part of the believers.

\section{Conclusion}

Big evangelization efforts began throughout the world after Peter had given the 'kerygma' speech and three thousand people were baptized on the very day of Pentecost. (Acc Act 2:41) The temporary Church ought to seek the methods to address humanity and help him to come near to God. Before the $13^{\text {th }}$ upcoming general assembly of the Synod of bishops about the new evangelization, we reflect on the mystery of Baptism in the theological and pastoral realm. "On the day of our Baptism the Church grafts us, as branches, on to the Paschal Mystery of Jesus, into His very Person. From this root we receive the precious sap that enables us to share in the divine life."13 Baptism is a beginning which leads us to the maturity of our Christian faith. The whole church, her shepherds and believers strive for this: to know the value of Baptism, to bear witness to life, to catechumenate the already baptized and to gain the unity between Baptism and life.

\section{References}

AQUINAS, T.: Summa theologica.

BENEDICT XVI.: Speech on st. Peter's square, May 6 ${ }^{\text {th }}, 2012$.

DACÍK, R.: Bůh ve svátostech, Olomouc: Krystal, 1948.

DELORME, J.: La pratique du babteme dans le Judaisme contemporain des origines chrétiennes. Lumiere et Vie, 1956.

DUFOUR, X. L: Slovník biblickej teológie, Zagreb: Kršćanskaja sadašnjost, 1990.

ĎURICA, J. (ed.): NOVÝ ZÁKON skomentármi a margináliami Jeruzalemskej Biblie, Trnava: Dobrá kniha, 2008.

Katechizmus katolíckej cirkvi. Trnava: SSV, 1999 (2. vyd.).

\footnotetext{
${ }^{13}$ BENEDIKT XVI.: Speech on st. Peter's square, May $6^{\text {th }}, 2012$.
} 
SUllivan, F. A.: Charizmy a Charizmatická obnova, Bratislava: Serafín, 1982.

ŠPIDLÍK, T. - RUPNIK, M. I.: Nové cesty pastorálni teologie, Olomouc: Refugium Velehrad-Roma s.r.o., 2008.

TANQUEREY, AD.: Brevior synopsis theologiae dogmaticae, editio decima, Paris: DESCLÉE\&SOCII, 1956. 